\title{
Utjecaj dodatka začina na prirodnu mikrofloru „Kore“" kaštradine tijekom tehnološkog procesa proizvodnje
}

Andrijana Kegalj ${ }^{\star *}$, Danijel Karolyi², Mirna Mrkonjić Fuka², Boro Mioć2

\section{Sažetak}

Tradicijski hrvatski suhomesnati proizvod, kaštradina, proizvodi se od ovčjeg ili kozjeg mesa, najčešće isluženih ovaca ili muških kastrata. Sastav prirodne mikroflore svakog tradicijskog proizvoda je specifičan i ima važnu ulogu u razvoju tipičnih senzorskih svojstava samog proizvoda. Za poboljšanje senzorskih karakteristika dodaju se začini koji, osim što doprinose aromi samog proizvoda, imaju i antimikrobno djelovanje. Cilj ovog rada bio je istražiti utjecaj dodanih začina (češnjak, ružmarin i lovor) na prirodnu mikrofloru „kore“ kaštradine. Istraživanjem je bilo obuhvaćeno 20 trupova ovaca pasmine travnička pramenka. Nakon 24-satnog hlađenja trupovi su rasječeni na polovice, a sa svake polovice je odvojen but s potkoljenicom i plećka sa podlatkicom. Preostali dio trupa se naziva „kora“. Primijenjene su dvije varijante soljenja mesa: soljenje solju, te soljenje komercijalnom smjesom soli i prirodnih začina (češnjak, lovor i ružmarin). Uzorci „kore“ kaštradine su uzimani prvog (sirovina), sedmog (nakon faze soljenja) te četrnaestog dana (nakon zrenja) tehnološkog procesa proizvodnje. Istraživane su slijedeće skupine mikroorganizama: ukupne aerobne mezofilne bakterije, bakterije mliječne kiseline, enterokoki, mikrokoki, kvasci i plijesni, Staphylococcus aureus, enterobakterije, koliformi, Escherichia coli, Salmonella spp., Listeria spp. i sulfitreducirajuće klostridije. Istraživani uzorci „kore“ kaštradine, bez obzira na tehnologiju proizvodnje bili su mikrobiološki ispravni. Dodani začini su negativno utjecali na prosječni broj koliforma i ukupnih aerobnih mezofilnih bakterija. S obzirom kako u uzorcima „kore“ kaštradine nisu dokazani patogeni (Escherichia coli, Salmonella spp., Listeria spp.) nije se mogao utvrditi utjecaj začina na njih.

Ključne riječi:,,kora“ kaštradine, začini, prirodna mikroflora

\section{Uvod}

Najpoznatiji tradicijski suhomesnati ovčji proizvod na hrvatskim, ponajviše dalmatinskim područjima je kaštradina. Prema dostupnim podacima, kaštradina se proizvodila još u srednjem vijeku od mesa starijih, jalovih ovaca i muških kastrata postupcima soljenja, odnosno salamurenja, dimljenja/sušenja i zrenja u ograničenoj dehidrataciji (Krvavica i sur., 2009.). Kaštradina se tradicijski proizvodi soljenjem čistom solju, no proizvođači su počeli dodavati začine s ciljem poboljšanja izgleda i kvalitete zrelog proizvoda. S obzirom da je Hrvatska mediteranska zemlja,

\footnotetext{
${ }^{1}$ dr. sc. Andrijana Kegalj, v. pred.; Veleučilište Marko Marulić u Kninu, Kralja Petra Krešimira IV 30, Knin, Hrvatska

${ }^{2}$ izv.prof.dr.sc. Danijel Karolyi, izv.prof.dr.sc. Mirna Mrkonjić Fuka; prof.dr.sc. Boro Mioč; Agronomski fakultet, Sveučilište u Zagrebu, 
tradicionalno se koriste brojne začinske i aromatske biljne vrste u kulinarstvu, proizvodnji likera i rakija travarica te u zanatskoj proizvodnji različitih kozmetičkih pripravaka. Neki od začina karakteristični za naše podneblje su: paprena metvica, timijan, bosiljak, peršin, kadulja, kopar, papar, kim, ružmarin, bijeli luk, feferoni, crvena paprika, list lovora, list duda, karanfilić, celer, vlasac, kumin, kopriva i drugi (Josipović i sur., 2016.). U tehnologiji mesa koriste se različiti oblici začina (cijele sjemenke ili listovi, samljeveni dijelovi biljke, sjeckane cijele ili dijelovi biljke, granule ili prah), što uglavnom ovisi o načinu prerade mesa. Pored toga, u uporabi su i tzv. začinski oleoresini (uljne smole), esencijalna ulja i inkapsulirana esencijalna ulja (Tainter i Grenis, 2001.). Svaki od začina sadrži specifične sastojke od kojih potječe karakterističan okus i aroma. lako se začine dodaje najvećim dijelom zbog poboljšanja okusa, većina autora (Ankri i Mirelman, 1999., Davidson i Naidu, 2000. Chmit i sur., 2014.) tvrdi kako začini imaju značajnu ulogu u usporavanju mikrobnog kvarenja mesa, te poboljšavaju mliječno-kiselinsku fermentaciju. Međutim, temeljni problem koji se javlja pri pokušaju korištenja začina kao konzervansa je pronaći pravu kombinaciju, odnosno balans između utjecaja na okus hrane i količine začina potrebne za sprječavanje rasta patogena, a prema Cogginsu (2001.) količina začina potrebna za antimikrobnu aktivnost je 1-10\%.

Češnjak (Allium sativum) je široko poznat po svojim antivirusnim, antifungalnim i antibakterijskim svojstvima. Većinu ljekovitih svojstava češnjaku daje više od stotinu sumpornih spojeva od kojih su najpoznatiji alicin, alin i ajoen. Gnječenjem češnjaka oslobađa se alin koji djelovanjem alinaze koja se nalazi u stanicama prelazi u alicin koji češnjaku daje karakterističan miris i ima antimikrobna svojstva. Antimikrobna aktivnost alicina je u tome što se veže za tiolne skupine različitih bakterijskih enzima što dovodi do poremećaja bakterijskog metabolizma (Ankri i Mirelman,1999.). Kumar i Berwal (1998.) navode kako češnjak sadrži $0,3-0,5 \%$ alicina, te da su gram pozitivne bakterije osjetljivije na alicin od gram negativnih, dok većina drugih autora navode kako je alicin jednako djelotvoran i protiv gram pozitivnih i gram negativnih bakterija (Hamza, 2015., Benzemiane i sur., 2018., Leontiev i sur., 2018.).

Dokazano je kako ružmarin (Rosmarinus officinalis) u postotku od $0,3 \%$ djeluje bakteriostat- ski, a u 0,5\% koncentraciji baktericidno na gram pozitivne bakterije (Davidson i Zivanovic, 2003.). Za antibakterijsko djelovanje ružmarina odgovorni su fenolni diterpenoidi, koji su glavni spojevi nepolarne frakcije ekstrakta ružmarina (Fernández-López i sur., 2005.).

Listovi lovora (Laurus nobilis) sadrže 1-3 \% eteričnog ulja u kojem su glavni sastojci terpeni pinen i cineol. Esencijalno ulje lovora pokazuje jako antimikrobno i antifungalno djelovanje protiv velikog broja patogenih bakterija i uzročnika kvarenja hrane (Chmit i sur., 2014.).

Cilj ovoga rada bio je utvrditi dominantnu mikrofloru „kore“ kaštradine, te utjecaj začina (češnjak, lovor i ružmarin) na nju.

\section{Materijali $i$ metode}

\section{Proizvodnja kaštradine i uzorkovanje}

Za proizvodnju kaštradine korišteno je ukupno 20 trupova ovaca pasmine travnička pramenka. Klanje ovaca obavljeno je u ovlaštenoj klaonici, a trupovi su podvrgnuti standardnim postupcima obrade. Nakon klanja i 24-satnog hlađenja na $+4{ }^{\circ} \mathrm{C}$ trupovi su rasječeni na polovice, a sa svake polovice odvojen je but s potkoljenicom od slabine i trbušine rezom između zadnjeg slabinskog i prvog križnog kralješka, kao i plećka s podlakticom koja je od vrata, rebara i prsa odvojena rezom po prirodnoj mišićnoj vezi. Preostali, treći dio polovice naziva se „kora“. Ovako rasječeni dijelovi trupa podvrgnuti su procesu prerade koji je obuhvaćao sljedeće faze: soljenje ili suho salamurenje i dimljenje, odnosno sušenje. Sirovina je podijeljena u dvije skupine: dijelovi dobiveni od lijevih polovica označeni su oznakom $L$ te su soljeni čistom solju (Skupina 2), dok su dijelovi dobiveni od desnih polovica označeni oznakom $D$ i soljeni su suhom salamurom (Skupina 1). Smjesa suhe salamura bila je sastavljena od ukupno $99,63 \%$ soli i $0,37 \%$ mljevenih začina. Komercijalna smjesa začina s certifikatom o mikrobiološkoj ispravnosti (zadovoljeni parametri iz Vodiča za mikrobiološke kriterije za hranu, Anon.,2011.) sastojala se od 0,2 \% češnjaka, $0,02 \%$ lovora i $0,03 \%$ ružmarina. Nakon rasijecanja meso je soljeno snažnim utrljavanjem, te polagano u plastične posude. Svaki red je još jednom dosoljen. Utrošeno je ukupno $7 \%$ soli ili suhe salamure na ukupnu masu mesa. Temperatura u prostoriji u kojoj je držano soljeno meso bila je u rasponu od 0 do 5 
${ }^{\circ} \mathrm{C}$, a relativna vlažnost $80-90 \%$. Nakon sedam dana meso je izvađeno iz soli, odnosno suhe salamure, isprano hladnom vodom, ocijeđeno $\mathrm{i}$ ostavljeno $\mathrm{u}$ prostoriju za dimljenje. Hladno dimljenje i sušenje trajalo je za kore 7 dana, temperatura zraka u prostoriji za dimljenje iznosila je $16-20^{\circ} \mathrm{C}$. Za proizvodnju hladnog dima koristila su se tvrda drva (grab, bukva, hrast). Za vrijeme južnih vjetrova primijenilo se hladno dimljenje, dok se za vrijeme bure meso izložilo propuhu i sušilo.

\section{Mikrobiološka analiza}

Za mikrobiološku pretragu iz svake skupine „kore“ kaštradine uzeto je po 20 uzoraka $\mathrm{m}$. longi-

Tablica 1. Metodologija mikrobioloških pretraga Table 1 Methodology of microbiological analyses

\begin{tabular}{|c|c|c|c|}
\hline $\begin{array}{l}\text { Mikroorganizmi/ } \\
\text { Microorganisms }\end{array}$ & Metoda/Method & $\begin{array}{l}\text { Hranjiva podloga/ } \\
\text { Nutrient media }\end{array}$ & $\begin{array}{l}\text { Uvjeti inkubacije/ } \\
\text { incubation condition }\end{array}$ \\
\hline $\begin{array}{l}\text { Aerobne mezofilne bakterije/ } \\
\text { Aerobic mesophilic bacteria }\end{array}$ & HRN ISO 4833:2003 & $\begin{array}{l}\text { PCA agar (Merck, Darmstadt, } \\
\text { Njemačka) }\end{array}$ & $\begin{array}{r}30^{\circ} \mathrm{C} \\
48 \mathrm{~h}\end{array}$ \\
\hline Staphylococcus aureus & HRN ISO 6888-1:2004 & BP agar (Biolife, Milano, Italija) & $\begin{array}{r}37^{\circ} \mathrm{C} \\
24-48 \mathrm{~h}\end{array}$ \\
\hline Enterobacteriaceae & HRN ISO 5552:1999 & $\begin{array}{l}\text { VRBG agar (Biolife, Mialno, } \\
\text { Italija) }\end{array}$ & $\begin{array}{r}37^{\circ} \mathrm{C} \\
24 \mathrm{~h}\end{array}$ \\
\hline Listeria monocytogenes & HRN EN ISO 11290-1:1999 & $\begin{array}{l}\text { PALCAM agar, Oxford (Biolife, } \\
\text { Milano, Italija) }\end{array}$ & $\begin{array}{r}30^{\circ} \mathrm{C}-37^{\circ} \mathrm{C} \\
24 \mathrm{~h} \mathrm{i} 28 \mathrm{~h}\end{array}$ \\
\hline Salmonella spp. & HRN EN ISO 6579:2003 & $\begin{array}{l}\text { BPLS, XLD agar (Merck, Merck, } \\
\text { Darmstadt, Njemačka) }\end{array}$ & $\begin{array}{r}37^{\circ} \mathrm{C} \\
24 \mathrm{~h} \mathrm{i} 48 \mathrm{~h}\end{array}$ \\
\hline $\begin{array}{l}\text { Sulfitreducirajuće klostridije/ } \\
\text { Sulphite reducing Clostridia }\end{array}$ & HRN ISO 15213:2004 & SPS (Biolife, Milano, Italija) & $\begin{array}{r}37^{\circ} \mathrm{C} \\
72 \mathrm{~h}\end{array}$ \\
\hline $\begin{array}{l}\text { Kvasci i plijesni/Yeasts and } \\
\text { moulds }\end{array}$ & HRN ISO 13681:2001 & $\begin{array}{l}\text { Sabourand agar (Biolife, } \\
\text { Milano, Italija) }\end{array}$ & $\begin{array}{r}25^{\circ} \mathrm{C} \\
48 \mathrm{~h}\end{array}$ \\
\hline $\begin{array}{l}\text { Bakterije mliječne kiseline/ } \\
\text { Lactic acid bacteria }\end{array}$ & ISO 13721:1995 & $\begin{array}{l}\text { MRS agar (Biolife, Milano, } \\
\text { Italija) }\end{array}$ & $\begin{array}{r}37^{\circ} \mathrm{C} \\
48-72 \mathrm{~h} \\
\end{array}$ \\
\hline Koliformi/Coliforms & * & $\begin{array}{l}\text { Coli ID agar (Bio Merieux, Marcy } \\
\text { I'Etoile, Francuska) }\end{array}$ & $\begin{array}{r}37^{\circ} \mathrm{C} \\
24 \mathrm{~h}\end{array}$ \\
\hline Enterococcus spp. & * & $\begin{array}{l}\text { Kanamycin aesculin azide agar } \\
\text { (Merck, Darmstadt, Njemačka) }\end{array}$ & $\begin{array}{r}37^{\circ} \mathrm{C} \\
48 \mathrm{~h}\end{array}$ \\
\hline Micrococcus spp. & * & $\begin{array}{l}\text { Mannitol salt agar (Bio Merieux, } \\
\text { Marcy l'Etoile, Francuska) }\end{array}$ & $\begin{array}{r}30^{\circ} \mathrm{C} \\
48 \mathrm{~h}\end{array}$ \\
\hline E. coli & * & $\begin{array}{l}\text { Coli-ID agar (Bio Merieux, } \\
\text { Marcy l'Etoile, Francuska) }\end{array}$ & $\begin{array}{r}37^{\circ} \mathrm{C} \\
24 \mathrm{~h}\end{array}$ \\
\hline
\end{tabular}

* prema Zdolec i sur. (2008.) / according Zdolec et al. (2008)

\section{Statistička analiza podataka}

Iz dobivenih kvantitativnih rezultata mikrobiološkog rasta izračunati su deskriptivni statistički parametri. U cilju utvrđivanja dominantne populacije mikroorganizama tijekom pojedinih faza proizvodnje „kore“ kaštradine, razlike između srednjih vrijednosti rasta pojedinih skupina i vrsta ssimus dorsi (MLD),, i to sirovog mesa prije soljenja (1. dan), potom mesa nakon faze soljenja (7. dan), te zrele "kore“ kaštradine nakon faze dimljenja i zrenja (14. dan). Uzorci su do mikrobiološke analize pohranjeni u sterilne PVC vrećice na $+4{ }^{\circ} \mathrm{C}$. U uzorcima su klasičnim kulturelnim mikrobiološkim metodama (Tablica 1) određene sljedeće skupine i vrste mikroorganizama: ukupne aerobne mezofilne bakterije, bakterije mliječne kiseline, enterokoki, mikrokoki, sulfitreducirajuće klostridije, bakterije Salmonella spp., enterobakterije, koliformi, Escherichia coli, Staphylococcus aureus, kvasci i plijesni, te Listeria spp. 


\section{Rezultati i rasprava}

Kao što je vidljivo iz rezultata prikazanih u Tablicama 2 i 3, kod obje tehnologije (Skupina 1 i Skupina 2) tijekom faze soljenja statistički značajno $(P<0,05)$ povećao se prosječni broj ukupnih aerobnih mezofilnih bakterija, bakterija mliječne kiseline, mikrokoka, enterokoka, te kvasaca i plijesni. Prosječni broj $S$. aureusa se smanjio, no statistički značajna $(P<0,05)$ redukcija njegovog rasta je zapažena u uzorcima Skupine 1 . Zrenje nije imalo statistički značajnog utjecaja na prosječni broj ispitivanih skupina mikroorganizama ni u jednoj skupini. Ukoliko se usporedi prosječni broj mikroorganizama u sirovini i u zrelim uzorcima, tada je vidljivo kako je broj ukupnih aerobnih mezofilnih bakterija, bakterija mliječne kiseline, te kvasaca i plijesni statistički značajno veći $(P<0,05)$ u zrelim uzorcima nego u sirovini Skupine 2, dok je u uzorcima Skupine 1 samo prosječni broj kvasaca i plijesni statistički značajno veći $(P<0,05)$ u zrelim uzorcima nego u sirovini. Patogeni mikroorganizmi (E. coli, Clostridium spp., Listeria spp. i Salmonella spp.) nisu izolirane ni u jednom uzorku iz obje skupine bez obzira na fazu proizvodnje.

Tablica 2. Dinamika mikrobnog rasta u različitim fazama tehnološkog procesa proizvodnje „kore“ kaštradine soljenjem smjesom soli i začina (Skupina 1).

Table 2 Dynamics of microbial growth in different phases of technological process of production of "kora" kastradina by salting with mixture of salt and spices (Group 1)

\begin{tabular}{|c|c|c|c|}
\hline \multirow{2}{*}{$\begin{array}{l}\text { Mikroorganizmi/ } \\
\text { Microorganisms }\end{array}$} & \multicolumn{3}{|c|}{$M \pm S D(\log c f u / g)$} \\
\hline & $\frac{1}{\text { (raw meat) } n=20}$ & $\frac{7}{\text { (after salting) } n=20}$ & $\underset{n=20}{14}$ \\
\hline AMB & $4,83 \pm 0,83 a$ & $6,14 \pm 0,85 b$ & $5,55 \pm 2,46 a b$ \\
\hline BMK / LAB & $3,36 \pm 0,52 a$ & $4,38 \pm 0,60 \mathrm{~b}$ & $4,00 \pm 1,82 a b$ \\
\hline Micrococcus spp. & $3,07 \pm 0,67 a$ & $4,46 \pm 1,08 b$ & $3,92 \pm 1,77 a b$ \\
\hline Staphylococcus aureus & $1,19 \pm 1,30 \mathrm{a}$ & $0,33 \pm 0,81 b$ & $0,00 \pm 0,00 \mathrm{~b}$ \\
\hline $\begin{array}{l}\text { Enterobakterije/ } \\
\text { Enterobacteria }\end{array}$ & $1,62 \pm 1,48 a$ & $0,87 \pm 1,25 a$ & $0,67 \pm 1,24 a$ \\
\hline Enterococcus spp. & $3,08 \pm 0,52 a$ & $4,40 \pm 1,00 \mathrm{~b}$ & $3,73 \pm 1,69 \mathrm{ab}$ \\
\hline Koliformi/Coliforms & $0,92 \pm 1,05 a$ & $0,56 \pm 0,94 a$ & $0,45 \pm 0,85 a$ \\
\hline $\begin{array}{l}\text { Kvasci i plijesni/ } \\
\text { Yeasts and moulds }\end{array}$ & $3,03 \pm 0,44 a$ & $4,77 \pm 0,62 b$ & $4,13 \pm 1,82 b$ \\
\hline Escherichia coli & $N^{\star}{ }^{\star}$ & $\mathrm{ND}^{*}$ & $N^{*}$ \\
\hline Clostridium spp. & $\mathrm{ND}^{*}$ & $\mathrm{ND}^{*}$ & $N D^{\star}$ \\
\hline Listeria spp. & $N^{*}$ & $N^{*}$ & $N^{\star}{ }^{\star}$ \\
\hline Salmonella spp. & $N D^{\star \star}$ & $\mathrm{ND}^{\star *}$ & $N D^{\star \star}$ \\
\hline
\end{tabular}

M-srednja vrijednost/mean value; SD-standardna devijacija/standard deviation AMB-aerobne mezofilne bakterije/aerobic mezophilic bacteria; BMK-bakterije mliječne kiseline/LAB lactic acid bacteria; $a$,b-srednje vrijednosti u istom redu sa različitim eksponentima statistički se značajno razlikuju $(P<0,05) /$; mean values in the same row with different letters differ significantly $(P<0.05) ; N D^{*}$-nije detektiran u 1 $\mathrm{g} /$ not detected in $1 \mathrm{~g} ; \mathrm{ND}^{\star \star}$-nije detektiran u $25 \mathrm{~g} /$ not detected in $25 \mathrm{~g}$

U predmetnom istraživanju (Tablice 2 i 3) u sirovini je utvrđen je prosječan broj aerobnih mezofilnih bakterija od 4,68-4,83 log cfu/g, koji je viši u odnosu na oko $3 \log \mathrm{cfu} / \mathrm{g}$ u sirovini za proizvodnju lacóna kako navode Lorenzo i sur. (2010.), no dosta od broja bakterija od 6 log cfu/g koji su utvrdili Vilar i sur. (2000.). Razlike u početnom broju aerobnih mezofilnih bakterija odražavaju razlike u kvaliteti sirovine i kontaminaciji tijekom procesa obrade. $U$ našem istraživanju, nakon faze soljenja je prosječni broj aerobnih mezofilnih bakterija dosegnuo svoj maksimum od 6,14-6,27 $\log \mathrm{cfu} / \mathrm{g}$, te se sušenjem smanjio na 5,55-6,05 log cfu/g, no to smanjenje nije bilo statistički značajno. Slične nalaze navode García i sur. (2000.) za iberijsku šunku u kojoj je nakon soljenja utvrđen prosječni broj aerobnih mezofilnih bakterija od 3,98x105 cfu/g, Losantos i sur. (2000.) utvrdili su $10^{3}-10^{4} \mathrm{cfu} / \mathrm{g}$, te Molinero i sur. (2008.), koji navode manji broj aerobnih mezofilnih bakterija u zrelom 
Tablica 3. Promjena broja određene skupine mikroorganizama $\left(\log _{10} \mathrm{cfu} / \mathrm{g}\right)$ po određenim fazama tehnološkog procesa soljenja čistom solju (skupina 2) tijekom 14 dana proizvodnje

Table 3 Changes in microbial counts $\left(\log _{10} \mathrm{cfu} / \mathrm{g}\right)$ by certain stages of the technological process of salting with pure salt (Group 2) for 14 days kastradina production $(\mathrm{N}=20)$

\begin{tabular}{|c|c|c|c|}
\hline \multirow[t]{2}{*}{$\begin{array}{l}\text { Skupina mikroorganizama } \\
\text { /Microbial group }\end{array}$} & \multicolumn{3}{|c|}{$\begin{array}{c}\text { M } \pm \text { SD (log cfu/g) } \\
\text { Dani proizvodnje/Days of production }\end{array}$} \\
\hline & 1 & 7 & 14 \\
\hline AMB & $4,68 \pm 0,40 a$ & $6,27 \pm 0,56 b$ & $6,05 \pm 0,69 b$ \\
\hline $\mathrm{BMK} / \mathrm{LAB}$ & $2,93 \pm 0,28 a$ & $4,34 \pm 0,59 b$ & $3,93 \pm 1,47 b$ \\
\hline Micrococcus spp. & $3,12 \pm 0,71 a$ & $4,28 \pm 0,92 b$ & $3,87 \pm 1,49 a b$ \\
\hline Staphylococcus aureus & $0,72 \pm 1,14 a$ & $0,70 \pm 1,14 a b$ & $0,00 \pm 0,00 \mathrm{~b}$ \\
\hline $\begin{array}{l}\text { Enterobakterije/ } \\
\text { Enterobacteria }\end{array}$ & $1,12 \pm 1,12 a$ & $0,92 \pm 1,22 a$ & $0,84 \pm 1,29 a$ \\
\hline Enterococcus spp. & $2,96 \pm 0,50 a$ & $4,06 \pm 1,07 b$ & $3,54 \pm 1,43 a b$ \\
\hline Koliformi/Coliforms & $1,41 \pm 1,25 a$ & $1,37 \pm 1,41 a$ & $1,37 \pm 1,44 a$ \\
\hline $\begin{array}{l}\text { Kvasci i plijesni/ } \\
\text { Yeasts and moulds }\end{array}$ & $3,14 \pm 0,70 a$ & $4,06 \pm 0,72 b$ & $4,38 \pm 1,59 b$ \\
\hline Escherichia coli & $N D^{*}$ & $N D^{*}$ & $N D^{\star}$ \\
\hline Clostridium spp. & $N D^{*}$ & $N D^{*}$ & $N D^{*}$ \\
\hline Listeria spp. & $N^{*}$ & $N^{*}$ & $N^{*}$ \\
\hline Salmonella spp. & $N D^{\star \star}$ & $N D^{\star \star}$ & $N D^{\star \star}$ \\
\hline
\end{tabular}

$N$-broj uzorak / number of samples; M-srednja vrijednost / Mean value; SD-standardna devijacija / Standard Deviation AMB-aerobne mezofilne bakterije / Aerobic mezophilic bacteria; BMK-bakterije mliječne kiseline / LAB Lactic acid bacteria; $a, b$-srednje vrijednostis različitim eksponentima statistički se značajno razlikuju $(P<0,05) /$; Values in the same row not followed by a common letter differ significantly $(P<0.05) ; N D^{*}$-nije detektiran u $1 \mathrm{~g} /$ not detected in $1 \mathrm{~g} ; \mathrm{ND}^{\star \star}$-nije detektiran u $25 \mathrm{~g} /$ not detected in $25 \mathrm{~g}$

španjolskom pršutu, odnosno cecini $(4,05 \log \mathrm{cfu} / \mathrm{g}$ 210. dan zrenja, 3,82 log cfu/g 270 dan zrenja, a na kraju proizvodnje, 360 . dan, bio je 3,64 log cfu/g. Nasuprot tome, Naidoo i Lindsay (2010.) utvrdili su znatno viši broj aerobnih mezofilnih bakterija u biltongu, suhomesnatom proizvodu iz Južne Afrike $\left(6,14-7,01 \times 10^{6} \mathrm{cfu} / \mathrm{g}\right)$, te Lorenzo i sur. (2010.) u lacónu (6 log cfu/g).

Broj bakterija mliječne kiseline (BMK) statistički značajno raste tijekom faze soljenja (Tablica 2 i 3). Povećanje broja BMK tijekom soljenja može se objasniti njihovom halotolerantnošću. Takva dinamika promjene broja BMK vrlo je slična onoj koju navode brojni autori koji su istraživali mikrofloru različitih suhomesnatih proizvoda (García i sur., 1995., Vilar i sur., 2000., Kaban, 2009., Rong-Jen i sur., 2010.). Prosječni broj BMK u našem istraživanju se smanjivao tokom zrenja, no to smanjenje nije bilo statistički značajno, što je u suglasju s rezultatima koje navode García i sur. (1995.) te Vilar i sur. (2000.).

Kao što je vidljivo iz Tablica 2 i 3, broj enterokoka se statistički značajno povećavao tijekom faze soljenja, dok im se sušenjem broj smanjuje, no to smanjenje nije statistički značajno. Slične rezultate navode Rong-Jen i sur. (2010.) i Kilic (2009.) koji tvrde da se enterokoki zbog svoje halotolerantnosti mogu udvostručiti tijekom faze soljenja, dok Paarup i sur. (1999.) opisuju dosta niži broj enterokoka u zreloj šunki. Nasuprot tome, Vilar i sur. (2000.) su dokazali enterokoke na površini i unutrašnjosti samo svježe šunke, s naglaskom da im se na površini broj smanjivao tijekom proizvodnje i skoro su nestali do kraja faze zrenja.

Prosječni broj mikrokoka se mijenjao tijekom proizvodnje slično kao i populacija enterokoka, te su u zrelom proizvodu pokazali rast u uskom rasponu od 3,87 log cfu/g do 3,92 log cfu/g. Povećanje broja mikrokoka kao halotolerantne mikroflore nakon faze soljenja naveli su i drugi autori koji su istraživali promjenu mikroflore tijekom tehnološkog procesa proizvodnje različitih suhomesnatih proizvoda (Rodriguez i sur., 1996., Vilar i sur., 2000., Kaban, 2009., Lorenzo i sur., 2010.) utvrđujući mikrokoke kao dominantnu mikrofloru većine suhomesnatih proizvoda.

$\mathrm{U}$ sirovini je izoliran neznatan broj enterobakterija i koliforma, te se njihov broj neznatno 
smanjujetijekom proizvodnje (Tablice $2 \mathrm{i} 3$ ). Prisutnost enterobakterija i koliforma u proizvodu pokazatelj su slabe higijene i propusta tijekom proizvodnje i skladištenja „kore“ kaštradine. Njihova prisutnost u sirovini i zrelom proizvodu može ukazivati na nedostatne higijenske uvjete i nepravilan rad u klaonici, odnosno na fekalno zagađenje mesa tijekom klanja i kritičnih postupaka klaoničke obrade trupa, kao što su skidanje kože ili evisceracija. Nasuprot tome, obzirom da se broj enterobakterija i koliforma nije povećavao tijekom proizvodnje, može se zaključiti da su higijenski uvjeti tijekom proizvodnje „kore“ kaštradine zadovoljavajući. lako je dokazan određeni broj enterobakterija u proizvodu, kaštradina odgovara preporukama Vodiča (Anon, 2011) koji navodi granične vrijednosti broja enterobakterija u zrelim suhomesnatim proizvodima koji se kreće od 0 do $2 \log$ cfu/g. Većina autora (Paarup i sur., 1999., García i sur., 2000., Vilar i sur., 2000., Molinero i sur., 2008., Kaban, 2009.) utvrdili su mali broj enterobakterija u sirovini za proizvodnju suhomesnatog proizvoda, no u zrelom proizvodu ih nisu detektirali (razina detekcije $<2 \log \mathrm{cfu} / \mathrm{g}$ ). Prisutnost koliforma u zrelim suhomesnatim proizvodima ovisi o razini kontaminacije sirovine, te o uvjetima tijekom zrenja (Cherroud i sur., 2014.). Stoga je važno optimizirati uvjete zrenja proizvoda kako bi se reducirao broj enterobakterija i koliforma u proizvodu na kraju tehnološkog procesa proizvodnje. U sirovini za proizvodnju „kore“ kaštradine izoliran je neznatan broj S. aureus (oko 1 log cfu/g) koji tijekom tehnološkog procesa proizvodnje „kore“ kaštradine u potpunosti nestaje, što implicira mikrobiološku ispravnost finalnog proizvoda u pogledu stafilokokne kontaminacije uz uvjet primjene opisanog tehnološkog procesa proizvodnje. Navedeni rezultati u suglasju su s rezultatima Prgometa (1970.), Garcíe i sur. (1995.), Vilara i sur. (2000.), te Fulladose i sur. (2010.) koji tvrde kako nisu detektirali S. aureus $u$ zrelom suhomesnatom proizvodu što je garancija higijenske ispravnosti samog proizvoda. Brojna istraživanja dokazala su kako prisutnost BMK u većem broju inhibira rast bakterije $\mathrm{S}$. aures (Adams i Moss, 2008.), kao i temperatura okoliša ispod $8{ }^{\circ} \mathrm{C}$ (Valero i sur., 2009.). S obzirom da rezultati predmetnog istraživanja pokazuju povećanje broja BMK tijekom proizvodnje „kore“ kaštradine i s obzirom da se temperatura prostorije za soljenje kretala od 0 do $5{ }^{\circ} \mathrm{C}$, to bi mogli biti razlozi totalne eliminacije ove bakterijske vrste tijekom tehnološkog procesa proizvodnje.

Niti u jednom uzorku sirovine ili zrelog proizvoda nisu izolirane bakterije rodova Salmonella, Clostridium i Listeria, kao ni bakterija E. coli.

Prosječni broj kvasaca i plijesni u sirovini bio je oko $3 \log \mathrm{cfu} / \mathrm{g}$, tijekom faze soljenja broj im se značajno povećao, da bi ih u zrelom proizvodu bilo značajno više nego u sirovini (oko 4 log cfu/g). To povećanje se može objasniti njihovom sposobnošću brze prilagodbe uvjetima okoliša. Slične

Tablica 4. Utjecaj tehnologije proizvodnje na mikrofloru „kore“ kaštradine nakon faze dimljenja i sušenja. Table 4 The influence of production technology on microflora of "kora" kastradina after the smoking and drying phase.

\begin{tabular}{|c|c|c|}
\hline \multirow{2}{*}{$\begin{array}{l}\text { Skupina mikroorganizama / Mi- } \\
\text { crobial group }\end{array}$} & \multicolumn{2}{|c|}{$M \pm S D(\log c f u / g)$} \\
\hline & $\begin{array}{l}\text { Soljenje čistom solju / } \\
\text { Salting with pure salt } \\
\qquad(n=20)\end{array}$ & $\begin{array}{l}\text { Soljenje smjesom soli i začina / } \\
\text { Salting with a mixture of salt and } \\
\text { spices }(n=20)\end{array}$ \\
\hline AMB & $6,05 \pm 0,69 a$ & $5,55 \pm 2,46 b$ \\
\hline $\mathrm{BMK} / \mathrm{LAB}$ & $3,93 \pm 1,47 a$ & $4,00 \pm 1,82 a$ \\
\hline Micrococcus spp. & $3,87 \pm 1,49 a$ & $3,92 \pm 1,77 a$ \\
\hline Staphylococcus aureus & $0,00 \pm 0,00 \mathrm{a}$ & $0,00 \pm 0,00 a$ \\
\hline Enterobakterije/Enterobacteria & $0,84 \pm 1,29 a$ & $0,67 \pm 1,24 a$ \\
\hline Enterococcus spp. & $3,54 \pm 1,43 a$ & $3,73 \pm 1,69 a$ \\
\hline Koliformi/Coliforms & $1,37 \pm 1,44 a$ & $0,45 \pm 0,88 b$ \\
\hline Kvasci i pljesni/ Yeasts and moulds & $4,38 \pm 1,59 a$ & $4,13 \pm 1,82 a$ \\
\hline
\end{tabular}

N-broj uzoraka / number of samples; M-srednja vrijednost/Mean value; SD-standardna devijacija / Standard Deviation AMB-aerobne mezofilne bakterije / Aerobic mezophilic bacteria; BMK-bakterije mliječne kiseline / LAB Lactic acid bacteria; $a, b$-srednje vrijednostis različitim eksponentima statističkise značajno razlikuju $(P<0,05)$ /Values in the same row not followed by a common letter differ significantly $(P<0.05)$ 
rezultate navode i Vilar i sur. (2000.), koji su dokazali 4,22 log cfu/g kvasaca i plijesni u zrelom suhomesnatom proizvodu (lacón). S druge strane, Cherroud i sur. (2014.) navodi znatno manji broj kvasaca i plijesni u zrelom suhomesnatom proizvod $(2,81 \mathrm{log}$ cfu/g) u odnosu na naše istraživanje jednako kao i Gajić (2000.) u zreloj kaštradini (3,6 log cfu/g ) dok Gok i sur. (2008.) navode znatno viši broj kvasaca i pljesni u zreloj pastrmi od vrijednosti utvrđenih $u$ predmetnom istraživanju $(5,7 \log \mathrm{cfu} / \mathrm{g})$.

U našem istraživanju uočeno je kako dodatak začina (češnjak, lovor i ružmarin) u smjesu za soljenje negativno utječe na prosječni broj koliforma i ukupnih aerobnih mezofilnih bakterija, (Tablica 4). Broj ukupnih aerobnih mezofilnih bakterija je značajno niži $(P<0,05)$ u uzorcima koji su soljeni smjesom soli i začina nego u uzorcima koji su soljeni čistom soli. Ovakav nalaz potvrđuju ranija istraživanja koja navode kako su gram pozitivne bakterije osjetljive na aktivne tvari iz ružmarina i češnjaka (Kumar i Berwal, 1998., Davidson i Zivanovic, 2003., Sallam i sur., 2004., Zhang i sur. 2016., El-Sherif i El-Ghafour, 2016.). Međutim, BMK, iako gram pozitivne, pokazuju visoku rezistentnost na antimikrobno djelovanje začina (Kumar i Berwal, 1998.), što može opravdati izostanak signifikantne razlike u prosječnom broju BMK između uzoraka „kore“ kaštradine soljene sa i bez dodatka začina (Tablica 4).

Dodatak začina negativno je utjecao i na prosječni broj koliforma, te je njihov rast statistički značajno $(P<0,05)$ niži u uzorcima Skupine 1 nego $\mathrm{u}$ onima Skupine 2. Ovaj rezultat je u suglasju s navodima Chabbouha i sur. (2013.) koji tvrde kako češnjak i maslinovo ulje smanjuju broj fekalnih koliforma za $23 \%$. Također, Zhang i sur. (2016.) navode kako je kombinacija začina ružmarina i češnjaka vrlo efikasna u smanjenju broja enterobakterija.

Bez obzira na primijenjenu tehnologiju soljenja, dominantnu mikrofloru zrele "kore“ kaštradine čine kvasci i plijesni (4,13-4,38 log cfu/g), bakterije mliječne kiseline (3,93-4,00 log cfu/g) i mikrokoki (3,87-3,92 log cfu/g), što je u suglasju s rezultatima većine autora koji su istraživali mikrofloru zrelih suhomesnatih proizvoda (García i sur., 1995., Özdemir i sur., 1999., Vilar i sur., 2000., Kaban, 2009., 2013., Kilic, 2009., Cherroud i sur., 2014.). Većina navedenih autora slaže se kako je razlika u brojnosti dominantne mikroflore različitih suhomesnatih proizvoda primarno rezultat različite tehnologije proizvodnje. Migowska-Calik i sur. (2014.) navode da slične metode proizvodnje i skladištenja rezultiraju sličnim mikrobiološkim statusom proizvoda. Značajne razlike su vidljive usporedbom mikrobiološke kvalitete mesnih proizvoda proizvedenih na različitim geografskim širinama, što autori objašnjavaju uporabom različitih sirovina, te proizvodnjom u iznimno različitim uvjetima.

\section{Zaključak}

Istraživanjem je utvrđeno kako je faza soljenja pozitivno utjecala na prosječni broj ukupnih aerobnih mezofilnih bakterija, bakterija mliječne kiseline, enterokoka, mikrokoka, te kvasaca i plijesni u oba tehnološka procesa proizvodnje „kore“ kaštradine. Nadalje, utvrđeno je da dominantnu mikrofloru zrele "kore“ kaštradine čine kvasci i plijesni, bakterije mliječne kiseline i mikrokoki. Dodatkom začina u smjesu za soljenje značajno se smanjio prosječni broj koliforma i ukupnih aerobnih mezofilnih bakterija. S druge strane, dodatak začina nije pokazao statistički značajan utjecaj na populacije BMK, mikrokoka, enterokoka, enterobakterija te kvasaca i plijesni u finalnom proizvodu. Utjecaj začina na patogene (Listeria spp, Salmonella spp, Clostriduim spp i E. coli) nije bilo moguće utvrditi s obzirom da nisu detektirani ni u jednom uzorku.

\section{References}

[1] Adams, M.R., M.O. Moss (2008): Food Microbiology, Third editions. RSC Publishing, Cambridge, UK.

[2] Ankri, S., D. Mirelman (1999): Antimicrobial properties of allicin from garlic. Microbes Infect 1(2), 125-129.

[3] Anonimno (2011): Vodič za mikrobiološke kriterije za hranu (3. izmijenjeno izdanje).

[4] Benzemiane, F., L. Djermoune-Arkoub, K. Adamou Hassan, H. Zeghad (2018): Evaluation of antibacterial activity of aqueous extract and essential oil from garlic against some pathogenic bacteria Int Food Res J 25(2), 561-564.

[5] Chabbouh, M., A. Sahli, S. Bellagha (2013): Does the spicing step affect the quality and drying behaviour of traditional kaddid, a Tunisian cured meat? J Sci Food Agr 93(14), 3634-3641.

[6] Cherroud, S., A. Cachaldora, S. Fonseca, A. Laglaoui, J. Carballo, I. Franco (2014): Microbiological and physicochemical charac- 
terization of dry-cured Halal goat meat. Effect of salting time and addition of olive oil and paprika covering. Meat Sci 98, 129-134.

[7] Chmit, M., H. Kanaan, J. Habib, M. Abbas, A. Mcheik, A. Choki (2014): Antibacterial and antibiofilm activities of polysaccharides, essential oil and fatty oil extracted from Laurus nobilis growing in Lebanon. Asian Pac J Trop Med 7(1), S546-S552.

[8] Coggins, P.C. (2001): Spices and Flavorings for Meat and Meat Products. U: Meat Science and Applications. Marcel Dekker, Inc. New York, Basel, 377-407.

[9] Davidson, P.M., A.S. Naidu (2000): Phytophenols. U: Natural food antimicrobial systems. A.S. CRC Press. Boca Raton, Florida: 265-295.

[10] Davidson, P.M., S. Zivanovic (2003): The use of natural antimicrobials. U: Food preservation techniques. Woodhead Publishing Limited. Cambridge, England. 14.

[11] El-Sherif, S.A., S.A. El-Ghafour (2016): Effectiveness of garlic, rosemary and ginger essential oils on improve the quality and shelf life of bagrus bayad fish sausage preserved by cold storage. Int J Adv Res 4(11), 276-289.

[12] Fernández-López, J., N. Zhi, L. Aleson-Carbonell, J.A. Pèrez-Alvarez, V. Kuri (2005): Antioxidant and antibacterial activities of natural extracts: application in beef meatballs. Meat Sci 69(3), 371-380.

[13] Fulladosa, E., M. Garriga, B. Martín, M.D. Guàrdia, J.A. García-Regueiro, J. Arnau (2010): Volatile profile and microbiological characterization of hollow defect in dry-cured ham. Meat Sci 86, 801-807.

[14] Gajić, B. (2000): Kontaminiranost suhomesnatih proizvoda supstancama štetnim po zdravlje ljudi . Magistarski rad. Poljoprivredni fakultet Sarajevo.

[15] García, I., J.M. Zumalacárregui, V. Díez (1995): Microbial succession and identification of Micrococcaceae in dried beef cecina, an intermediate moisture meat product. Food Microbiol 12. 309-315.

[16] García, C., A. Martín, M.L. Timón, J.J. Córdoba (2000): Microbial populations and volatile compounds in the 'bone taint' spoilage of dry cured ham. Lett Appl Microbiol 30, 61-66.

[17] Gok, V., E. Obuz, L. Akkaya (2008): Effects of packaging method and storage time on the chemical, microbiological, and sensory properties of Turkish pastirma -a dry cured beef product. Meat Sci 80(2), 335-344.

[18] Hamza, H.J. (2015): Antimicrobial Activity of Some Plant Extracts on Microbial Pathogens Isolated from Hilla City Hospitals, Iraq. Medical Journal of Babylon-Vol. 12 (2), 398-407.

[19] Josipović, Renata, Ksenija Markov, Jadranka Frece, D. Stanzer, A. Cvitković, Jasna Mrvčić (2016): Upotreba začina u proizvodnji tradicionalnih sireva. Mljekarstvo 66(1). 12-25.

[20] Kaban, G. (2009): Identification and characterisation of catalase positive cocci isolated from pastirma. Fleisch wirtschaft international 90(2), 104-106.

[21] Kaban, G. (2013): Sucuk and pastırma: Microbiological changes and formation of volatile compounds. Meat Sci 96, 912-918.

[22] Kilic, B. (2009): Current trends in traditional Turkish meat products and cuisine. Food Sci Tech 42,1581-1589.

[23] Kumar, M., J.S. Berwal (1998): Sensitivity of food pathogens to garlic (Allium sativum). J Appl Microbiol 84, 213-215.

[24] Krvavica, Marina, Emilija Friganović, Jelena Đugum, Andrijana Kegalj (2009): Dalmatinska kaštradina [koštradina]. Meso 11(5), 285-290.

[25] Leontiev, R., N. Hohaus, C. Jacob, M.S.H. Grulhke, A.J. Slusarenko (2018): Comparison of the Antibacterial and Antifungal Activities of Thiosulfinate Analogues of Allicin. Sci Rep 8, 6763.

[26] Lorenzo, M.J., M. García Fontán, A. Cachaldora, I. Franco, J. Carballo (2010): Study of the lactic acid bacteria throughout the manufacture of dry-cured lacón (a Spanish traditional meat product). Effect of some additives. Food Microbiol 27, 229-235.

[27] Losantos, A., C. Sanabria, I. Cornejo, A.V. Carrascosa (2000): Characterization of Enterobacteriaceae strains isolated from spoiled dry-cured hams. Food Microbiol 17, 505-512.

[28] Migowska-Calik, A., M. Gomółka-Pawlicka, J. Uradziński, T. Lachowicz (2014): Specificity of the production of traditional meat products and their safety using polish traditional cured meat products as example. Afr J Microbiol Res 8 (10), 1050-1059.

[29] Molinero, C., B. Martínez, B. Rubio, J. Rovira, I. Jaime (2008): The effects of extended curing on the microbiological, physicochemical and sensorial characteristics of Cecina de León. Meat Sci 80, 370-379.

[30] Naidoo, K., D. Lindsay (2010): Pathogens Associated with Biltong Product and Their in vitro Survival of Hurdles Used during Production. Food Protection Trends 30(9), 532-538.

[31] Özdemir, H., T.U. Şireli, B. Sarimehmetoglu, G. İnat (1999): Ankara'da Tüketime Sunulan PastÝrmalarda Mikrobiyal Floranin İncelenmesi. Turk J Vet Anim Sci 1, 57-62.

[32] Paarup, T., J.C. Nieto, C. Peláez, J.I. Reguera (1999): Microbiological and physicochemical characterisation of deep spoilage in Spanish dry-cured hams and characterisation of isolated Enterobacteriaceae with regard to salt and temperature tolerance. Eur Food Res Technol 209(5), 366-371.

[33] Prgomet, A. (1970): Prilog poznavanju proizvodnje i svojstava kaštradine u Dalmaciji. Magistarski rad. Veterinarski fakultet sveučilišta u Zagrebu.

[34] Rodrìguez, M., F. Nùñez, J.J. Córdoba, E. Bermúdez, M.A. Asensio (1996): Gram-Positive, Catalase-Positive Cocci from Dry Cured Iberian Ham and Their Enterotoxigenic Potential. Appl Environ Microb 62(6), 1897-1902.

[35] Rong-Jen, T., W. Hsiang-Yun, L. Ying-Shiang, C. Ming-Ju (2010): Evaluation of microbial dynamics during the ripening of a traditional Taiwanese naturally fermented ham. Food Microbiol 27, 460-467.

[36] Sallam, Kh.I., M. Ishioroshi, K. Samejima (2004): Antioxidant and antimicrobial effects of garlic in chicken sausage. Lebensm. Wiss uTechnol 37, 849-855.

[37] Tainter, D.R., A.T. Grenis (2001): Spices and Seasonings - A Food Technology Handbook. 2nd ed. New York: Wiley - VCH.

[38] Valero, A., F. Pérez-Rodríguez, E. Carrasco, J.M. Fuentes-Alventosa, R.M. García-Gimeno, G. Zurera, G. (2009): Modelling the growth boundaries of Staphylococcus aureus: Effect of temperature, $\mathrm{pH}$ and water activity. Int J Food Microbiol 133, 186-194.

[39] Vilar, I., M.C. García Fontán, B. Prieto, M.E Tornadijo, J. Carballo (2000): A survey on the microbiological changes during the manufacture of dry-cured lacón, a Spanish traditional meat product. J Appl Microbiol 89, 1018-1026.

[40] Zdolec, N., M. Hadžiosmanović, Lidija Kozačinski, Željka Cvrtila, Ivana Filipović, M. Škrivanko, Kristina Leskovar (2008): Micro- 
bial and physicochemical succession in fermented sausages produced with bacteriocinogenic culture of Lactobacillus sakei and semi-purified bacteriocin mesenterocin Y. Meat Sci 80, 480-487.

[41] Zhang, H., J. Wu, X. Guo, (2016): Effects of antimicrobial and antioxidant activities of spice extracts on raw chicken meat quality. Food Science and Human Wellness 5 (1), 39-48.

\section{The effect of added spices on natural "kora" microflora during the production of kastradina}

\section{ABSTRACT}

The traditional Croatian dry-cured meat product, kastradina, is produced from mutton, most often the meat of old ewes or wethers. The composition of natural microflora of each traditional product is specific and plays an important role in the development of its typical sensory characteristics. Spices, that, in addition to contributing to the aroma of the product itself, also have antimicrobial properties, are added to improve the sensory characteristics. The aim of this study was to examine the effect of added spices (garlic, rosemary and laurel) on the natural microflora of the "kora" of kastradina. The study was carried out on 20 carcasses of Travnik Pramenka sheep. After 24-hours of cooling, the carcasses were first cut in halves, upon which the haunch and the shoulder were separated from the half. The remaining part of the carcass is called "kora". Two types of meat salting were applied: salting using sea salt and salting using the commercial mixture of salt and natural spices (garlic, laurel and rosemary). The "kora" of kastradina was sampled on the 1st (raw meat), 7th (after the salting phase) and 14th (dry product) day of the technological production process. The following groups of microorganisms were examined: total aerobic mesophilic bacteria, lactic acid bacteria, enterococci, micrococci, yeasts and moulds, Staphylococcus aureus, enterobacteria, coliforms, Escherichia coli, Salmonella spp., Listeria spp., and sulfite-reducing clostridia. The examined samples "kora" of kastradina (Escherichia coli, Salmonella spp., Listeria spp.), were microbiologically correct, regardless of the production technology. Added spices had a negative effect on the average number of coliforms and the total aerobic mesophilic bacteria. Since no pathogens were detected in any of the samples of the "kora" of kastradina, it was not possible to determine the effect of spices on pathogens.

Key words: "kora" of kastradina, spices, natural microflora

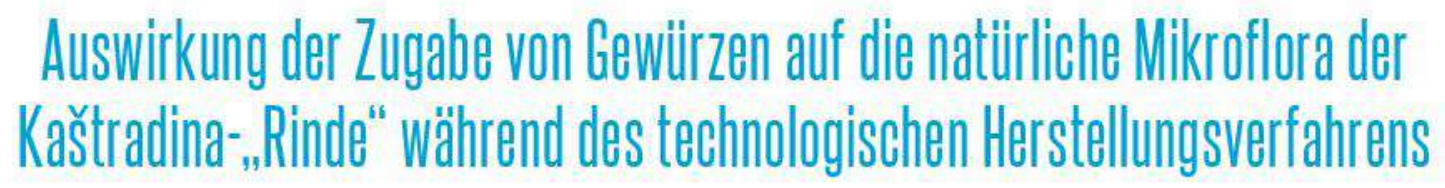

\section{Zusammenfassung}

Das traditionelle kroatische Dauerfleischprodukt Kaštradina wird aus Schaf- oder Ziegenfleisch hergestellt, am häufigsten von ausgedienten Schafen oder männlichen Kastraten. Die Zusammensetzung der Mikroflora eines jeden traditionellen Produkts ist spezifisch und spielt bei der Entfaltung der typischen sensorischen Eigenschaften des Produkts eine bedeutende Rolle. Um die sensorischen Eigenschaften zu verbessern, werden Gewürze zugegeben, die nicht nur das Aroma des Produkts verbessern, sondern auch über eine antimikrobielle Wirkung verfügen. Ziel dieser Arbeit war es, die Auswirkung der 
Gewürze (Knoblauch, Rosmarin und Lorbeer) auf die natürliche Mikroflora der Kaštradina-,,Rinde“ zu untersuchen. Die Untersuchung umfasste 20 Schafsrümpfe der Sorte Travnička pramenka. Nachdem die Rümpfe 24 Stunden gekühlt wurden, wurden sie in Hälften eingeteilt. Von jeder Hälfte wurden die Haxe mit der Keule und das Schulterblatt mit der Haxe abgetrennt. Der restliche Rumpfteil wird "Rinde“ genannt. Es wurden zwei Pökelungsverfahren angewendet: die Pökelung mit Salz und die Pökelung mit einer kommerziellen Mischung aus Salz und natürlichen Gewürzen (Knoblauch, Lorbeer und Rosmarin). Proben der „Rinde“ wurden am ersten Tag (Rohstoff), am siebten (nach der Pökelungsphase) und am vierzehnten Tag (nach der Reifung) des technologischen Herstellungsprozesses genommen. Die Proben wurden auf folgende Gruppen von Mikroorganismen untersucht: Gesamtanteil der aeroben mesophilen Bakterien, Milchsäurebakterien, Enterokokken und Mykrokokken, Hefen und Pilze, Staphylococus aureus, Enterobakterien, coliforme Bakterien, Escherichia coli, Salmonella spp., Listeria spp. und sulfitreduzierende Clostridien. Die Proben der „Rinde“ waren, ungeachtet der Herstellungstechnologie, mikrobiologisch einwandfrei. Die zugesetzten Gewürze haben sich negativ auf die durchschnittliche Anzahl der coliformen Bakterien und auf den Gesamtanteil der aeroben mesophilen Bakterien ausgewirkt. Da in den Proben der Kaštradine-„,Rinde“ keine pathogenen Bakterien nachgewiesen wurden (Escherichia coli, Salmonella spp., Listeria spp.), konnte die Auswirkung der Gewürze auf diese Bakterien nicht untersucht werden.

Schlüsselwörter: Kaštradina-Rinde, Gewürze, natürliche Mikroflora

\section{El impacto de las especias a la microflora natural de la "Kora" de la carne de carnero durante el processo tecnológico de la producción}

\section{Resumen}

El producto cárnico crudo-curado tradicional croata, la carne de carnero, se produce de la carne de oveja o de cabra, generalmente de ovejas viejas o carneros castrados. La composición de la microflora natural de cada producto tradicional es específica y tiene una función importante en el desarrollo de las características sensoriales del producto. Para la mejora de las características sensoriales se añaden las especias que, además de contribuir al aroma del producto, también son antimicrobianas. El fin de este trabajo fue investigar la influencia de las especias añadidas (el ajo, el romero y el laurel) sobre la microflora natural de la "kora" de la carne de carnero. La investigación incluyó 20 canales de las ovejas de la raza pramenka de Travnik. Después de 24 horas las canales fueron cortadas en medias canales, y de cada media canal fueron divididos el muslo con el jarrete y la paleta con el antebrazo. El resto de la canal se llama la "kora". Fueron aplicadas dos variantes del salazón de carne: el salazón por la sal y el salazón por la mezcla comercial de la sal y de las especias naturales (el ajo, el romero y el laurel). Las muestras de la "kora" fueron tomadas el primer (la materia prima), el séptimo (después de la fase de salazón) y el día catorce (después de la maduración) del proceso tecnológico de la producción. Fueron investigados siguientes grupos de microorganismos: bacterias mesófilas aerobias totales, bacterias del ácido láctico, bacterias mesófilas aerobias totales, bacterias del ácido láctico, enterococos, micrococos, levaduras y mohos, Staphylococcus aureus, enterobacterias, coliformes, Escherichia coli, Salmonella spp., Listeria spp. y clostridios reductores de sulfito. Las muestras investigadas de la carne de carnero, a pesar de la tecnología de la producción, fueron microbiológicamente seguras. Las especias añadidas afectaron negativamente el número total de los coliformes y de las bacterias mesófilas aerobias totales. Visto que en las muestras de la carne de carnero no fueron encontrados los patógenos (Escherichia coli, Salmonella spp., Listeria spp.), no fue posible determinar el impacto de las especias sobre ellos.

Palabras claves: „kora“ de la carne de carnero, especias, microflora natural 


\section{Impatto dell'aggiunta delle spezie sulla microflora naturale della "kora" della kaštradina durante il processo tecnologico della sua produzione}

\section{Riassunto}

In Croazia c'è un prodotto della tradizione gastronomica chiamato kaštradina che viene fatto essiccando le carni della pecora o del maschio castrato. La composizione della microflora naturale di ogni singolo prodotto tipico è specifica e gioca un ruolo importante nello sviluppo delle proprietà sensoriali tipiche del prodotto in sé. Per migliorare le caratteristiche sensoriali si aggiungono spezie che, oltre ad aromatizzare il prodotto, svolgono anche un'azione antimicrobica. Questo studio aveva lo scopo d'indagare l'impatto delle spezie aggiunte (aglio, rosmarino e alloro) sulla microflora naturale della "kora" della kaštradina. Lo studio ha coinvolto 20 carcasse di ovini di razza pramenka di Travnik. Dopo un raffreddamento durato 24 ore, le carcasse sono state tagliate in due mezzane, e da ogni mezzana sono stati messi da parte il cosciotto con lo stinco e la spalla sino al gomito. La parte residua della carcassa, usata per fare la kaštradina, in gergo di chiama "kora". La salagione della carne è stata eseguita secondo due modalità: la prima con il sale, la seconda con una miscela in commercio che comprende sia il sale, sia alcune spezie naturali (aglio, alloro e rosmarino). I campioni di "kora" sono stati prelevati il primo giorno (materia prima), il settimo giorno (dopo la fase della salagione) ed il quattordicesimo giorno (dopo la stagionatura) del processo tecnologico di produzione della kaštradina. L'analisi ha riguardato i seguenti gruppi di microrganismi: batteri aerobi mesofili totali, batteri dell'acido lattico, enterococchi, micrococchi, lieviti e muffe, Staphylococus aureus, enterobatteri, coliformi, Escherichia coli, Salmonella spp., Listeria spp. e clostridi solfito riduttori. I campioni esaminati di "kora", a prescindere dal processo tecnologico adottato, sono risultati microbiologicamente idonei. Le spezie aggiunte hanno avuto un impatto negativo sul numero medio di coliformi e di batteri aerobi mesofili totali. Poiché sui campioni di "kora" utilizzata per fare la kaštradina non sono stati rinvenuti microrganismi patogeni (Escherichia coli, Salmonella spp., Listeria spp.,) non è stato possibile accertare l'impatto su di essi.

Parole chiave: "kora" della kaštradina, spezie, microflora naturale

\section{PRVA ZNANSTVENA KONFERENCIJA RAWC-A O DOBROBITI ŽIVOTINJA}

\section{0. - 11. ožujka 2020. / Thessaloniki, Grčka}

Teme konferencije:

. Životinje u zajednicama (kućni ljubimci, nezbrinute životinje i životinje lutalice, dvorišni uzgoj i tradicionalna poljoprivreda, One Health...)

- Životinje u proizvodnji hrane (na farmi, u prijevozu, u klaonici...)

- Odnos između ljudi i životinja (društveno-ekonomski i etički kontekst...)

- Životinje i okoliš (ZOO, utjecaj stočarstva na klimu, zaštita staništa, upravljanje populacijom divljih životinja, modeliranje ekologije, One Welfare...)

. Životinje u istraživanju i obrazovanju (3R, analiza štete / koristi, humane krajnje točke...) 